\title{
GAYA KEPEMIMPINAN KEPALA SEKOLAH DALAM MENCAPAI AKREDITASI A (STUDI KASUS PADA SDN 24 LUAK BAYAU SULIT AIR KECAMATAN X KOTO DIATAS KABUPATEN SOLOK)
}

\author{
Hardianto \\ Guru PAI SDN 14 Ganting Dodok Sulit Air Kec. X Koto Diatas Kabupaten Solok \\ hardiantogazira@gmail.com
}

\begin{abstract}
Leadership style is pattern, method or action taken by a leader in affecting, moving, encouraging subordinates to work voluntarily to achieve the organitation objectives. The purpose of this study is to describe the style of leadership of SDN 24 Luak Bayau Sulit Air in achieving accreditation $A$. The kinds of research is describtion research with desain cases study. Data study were collected through interviews and documentation. The data collection technique used was snowball sampling. Data validity is tested through sourch triagulation. Sources and data analysis is done through a process of (1) data reduction, (2) Display of data, and (3) conclusion.The results showed the prinsipals leadership stayle SDN 24 Luak Bayau in achieving $A$ accreditation is democratic leadership stayle and partisipatif leadership stayle, task oriented and human relation leadership stayle.
\end{abstract}

Keyword: Leadership stayle, prinsipal and acreditation.

\section{PENDAHULUAN}

Keberhasilan

suatu

lembaga

pendidikan dalam mencapai tujuannya dipengaruhi oleh banyak faktor seperti siswa, kurikulum, sarana dan prasarana, kompetensi guru, kepala sekolah termasuk juga kebijakan yang diterapkan dalam mengelola pendidikan. Dari sejumlah faktor tersebut maka faktor kepemimpinan kepala merupakan hal yang sangat berpengaruh dalam mencapai visi dan misi yang telah ditetapkan sehingga maju atau mundurnya suatu sekolah sangat tergantung dari kepala sekolah yang bersangkutan dalam hal ini kepemimpinan dan lebih khusus lagi gaya kepemimpinannya.
Alasannya sebagai mana yang diungkapkan Suryadi (2009:1) adalah seorang manajer sebuah sekolah dan kepala sekolah dituntut sebenar - benarnya menjadi seorang pemimpin. Dalam arti ia harus mampu menggerakkan, mempengaruhi, memotivasi, mengajak, mengerahkan, dan bahkan menghukum serta membina, dengan maksud agar manusia sebagai media manajemen mau bekerja dalam rangka mencapai tujuan organisasi. Hal ini berarti kepala sekolah memiliki tanggung jawab menggerakkan seluruh komponen sekolah bekerja dengan baik dalam rangka mencapai mutu pendidikan baik aspek proses maupun hasilnya atau out putnya. 
Mulyasa

(2012:5)

juga

mengungkapkan bahwa kepala sekolah merupakan satu komponen pendidikan yang paling berperan dalam meningkatkan kualitas pendidikan. Sukses tidaknya pendidikan pembelajaran di sekolah sangat dipengaruhi oleh kemampuan kepala sekolah dalam mengelola dalam mengelola setiap komponen sekolah. Kemampuan yang diharapkan dari kepala sekolah terkait dengan pemahaman dan kemampuan manajemen dan kepemimpinan. Berhasil atau tidaknya suatu sekolah dalam mencapai tujuan, visi dan misinya terletak bagaimana manajemen dan kepemimpinan kepala sekolah khususnya dalam menggerakkan dan memberdayakan berbagai komponen sekolah.

Sementara itu, hal yang berpengaruh terhadap keberhasilan kepala sekolah sebagai seorang pemimpin adalah sebagai mana yang diungkapkan oleh Wahjosumidjo (2007:11) keperibadian, keahlian dasar, pengalaman dan pengatuhuan profesional, diklat dan keterampilan profesional, pengetahuan administrasi dan pengawasan. Dapat diambil suatu kesimpulan bahwa untuk menjadi pemimpin yang berhasil dan efektif seorang kepala sekolah sebagai seorang leader harus memiliki sejumlah keahlian atau kompetensi baik kompetensi peribadi, profesional maupun sosial dan seseorang dapat dikatakan sebagai pemimpin jika memiliki kelebihan dari yang dipimpinnya.

Menurut Nawawi (2006:115) gaya kepemimpinan adalah perilaku atau cara yang dipilih dan dipergunakan pemimpin dalam mempengaruhi pikiran, perasaan, sikap dan perilaku para anggota organisasi bawahannya. Sementara itu Fiedler (dalam Prasetyo,2006:28) gaya kepemimpinan adalah cara yang digunakan dalam proses kepemimpinan yang diimplementasikan dalam perilaku kepemimpinan seseorang untuk mempengaruhi orang lain untuk bertindak sesuai dengan apa yang diinginkan.

Berdasarkan definisi tersebut dapat disimpulkan bahwa gaya kepemimpinan adalah suatu cara atau pola perilaku seorang pemimpin yang khas pada saat mempengaruhi anak buahnya,apa yang dipilih oleh pemimpin untuk dikerjakan, cara pemimpin bertindak dalam mempengaruhi anggota kelompok untuk mencapai tujuan yang telah ditetapkan. Tingkah laku yang khas merupakan hal yang menjadi pembeda antara satu pemimpin dengan yang lainnya, setiap pemimpin memiliki cara tersendiri agar bawahannya bergerak dan termoivasi secara sukarela mencapai tujuan organisasi.sehingga dapat dikatakan gaya kepemimpinan yang digunakan oleh seorang pemimpin itu efektif ketika ia mampu mempengaruhi, mendorong, mengarahkan dan menggerakkan orang- orang yang dipimpin sesuai dengan situasi dan kondisi supaya mereka mau bekerja dengan penuh semangat dalam mencapai tujuan organisasi.

Gaya kepemimpinan seseorang tampak dalam kegiatan sehari-hari dalam hal bagaimana cara pemimpin memerintah, membagai tugas dan wewenangnya, cara berkomunikasi, cara mendorong semangat kerja bawahan, cara memberi pengawasan, cara membina disiplin kerja bawahan, cara menggerakkan dan memimpin rapat, dan cara mengambil keputusan. Apakah kepala 
sekolah lebih mementingkan tugas, kerja sama atau tugas dan kerja sama.

Kepala sekolah sebagai pemimpin lembaga pendidikan berfungsi sebagai penanggung jawab semua kegiatan di sekolah. Dalam perspektif kebijakan pendidikan nasional (Depdiknas, 2006) terdapat tujuh peran utama kepala sekolah, yaitu sebagai 1) edukator/pendidik, 2) manajer, 3) administrator, 4) supervisor/penyelia, 5) leader/pemimpin, 6) pencipta iklim kerja, dan 7) wirausahawan. Sehingga untuk mencapai tujuan tersebut kepala sekolah disyaratkn harus memiliki empat kompetensi yakni: kompetensi kepribadian, kompetensi manajerial, kompetensi kewirausahaan, kompetensi supervisi, dan kompetensi sosial.

Kepemimpinan Kepala Sekolah SDN 24 Luak Bayau Sulit Air Kecamatan X Koto Diatas merupakan salah kepala sekolah yang berhasil. Keberhasilan ini tidak terlepas gaya kepemimpinan atau cara kepala sekolah dalam memimpin seluruh warga sekolah untuk mecapai tujuan atau visi sekolah.

Dari beberapa data tentang keberhasilan atau kinerja kepala SDN 24 Luak Bayau seperti terciptanya suasana internal yang kondusif bagi pembelajaran antara guru, kepala sekolah maupun stakeholder pendidikan, pretasi akdemik maupun non akedemik yang dicapai oleh siswa dalam kurun waktu yang tidak begitu lama maka hal yang membuat peneliti ingin melakukan penelitian yaitu pencapain akreditasi A hal ini disebabkan dari 32 SD yang terdapat di Kecamatan X Koto Diatas Kabupaten Solok hanya 3 (tiga) sekolah yang memiliki akreditasi A yaitu SDN 14
Ganting Dodok Sulit Air, SDN 24 Luak Bayau Sulit Air dan SDN 22 Paninjauan. Dua sekolah yang memiliki akreditasi A ( SDN 14 Ganting Dodok dan 24 Luak Bayau) dipimpin oleh kepala sekolah yang sama yaitu Ibu Emalaili, S.Pd. Pada awalnya keberhasilan Ibu Emalaili dianggab sebagai kebetulan atau kedekatan dengan pejabat Dinas Pendidikan, hal tersebut terbantah dengan keberhasilannya dalam memimpin SDN 24 Luak Bayau Sulit mencapai akreditasi A meskipun belum lama menjadi kepala sekolah di sekolah tersebut.

Tujuan penelitian ini adalah mengungkap gaya kepemimpinan sekolah SDN 24 Luak Bayau dalam mencapai akreditasi yang dijabarkan 4 (empat) sub fokus yaitu (1) cara kepala sekolah dalam berkomunikasi untuk mencapai akreditasi A, (2) cara kepala sekolah membagi tugas warga sekolah dalam mencapai akreditasi A (3), cara kepala sekolah dalam melakukan pengawasan terhadap warga sekolah dalam mencapai akreditasi A, (4) cara kepala sekolah dalam menggerakkan warga sekolah dalam mencapai akreditasi A.

\section{Gaya Kepemimpinan Kepala Sekolah}

Kepemimpinan merupakan inti dari kegiatan manajemen dalam upaya pencapaian tujuan secara efektif dan efisien sehingga kehadiran seorang pemimpin dalam organisasi berimplikasi pada aksi dan interaksi para personil yang dalam suatu oragnisasi.Adenounmu (1986) dalam (T.O. Adeyemi dan R. Bolarinwa, 2013) menyatakan Leadership in any organization implies the action and interaction with persons and things with a view to attain a specific objective. It is the ability to plan, control, direct and 
coordinate the activities of school involving both buman and material resources for the achievement of school goals. It is a process through which persons or groups intentionally influence others in the attainment of group goals.

Kepemimpinan adalah suatu kemampuan peribadi sehingga dapat mempengaruhi individu, kelompok dan organisasi agar bersedia melakukan tindakan atau kegiatan untuk mencapai tujuan organisasi. Menurut Hikmat (2011:252) kepemimpinan adalah suatu seni, kesanggupan (ability) atau teknik untuk membuat sekelompok orang bawahan dan organisasi formal atau para pengikut atau para simpatisan dalam organisasi informal mengikuti atau menaati segala apa yang dikehendakinya, membuat mereka begitu antusias atau bersemangat untuk mengikutinya, bahkan mungkin rela berkorban untuknya.

Dalam mencapai tujuan yang diharapkan seorang pemimpin memiliki cara, strategi, perilaku ataupun tindakan tertentu agar orang yang berada di bawah kepemimpinannya dapat dipengaruhi agar bekerja mencapai tujuan yang telah ditetapkan bersama hal ini sering disebut gaya kepemimpinan. Gaya kepemimpinan setiap pemimpin pasti berbeda tergantung dari faktor-faktor yang berada di sekitar pemimpin tersebut maupun diri pemimpin yang bersangkutan.

Rivai dan Mulyadi mengungkapkan Gaya atau style kepemimpinan banyak mempengaruhi keberhasilan seorang pemimpin dalam memengaruhi perilaku- perilaku pengikutnya. Pemimpin yang efektif ialah pemimpin yang menggunakan gaya yang dapat mewujudkan sasarannya.Gaya artinya sikap, gerakan, tingkah laku, sikap yang elok, gerak-gerik yang bagus, kekuatan, kesanggupan untuk berbuat baik. Sedangkan gaya kepemimpinan adalah sekumpulan ciri yang digunakan pimpinan untuk mempengaruhi bawahan agar sasaran organisasi tercapai. Gaya kepemimpinan adalah pola perilaku dan strategi yang disukai dan sering diterapkan oleh seorang pemimpin.

Dalam melaksanakan fungsi-fungsi kepemimpinan, akan berlangsung aktivitas-aktivitas kepemimpinan. Apabila aktivitas tersebut dipilah-pilah, akan terlihat gaya kepemimpinan yang diterapkan dengan pola masing-masing pemimpin.

Tim dosen IKIP Malang (1989) membagi gaya kepemimpinan berdasarkan konsep, sikap, sifat dan cara pemimpin dalam melaksanakan kegiatan kepemimpinan menjadi empat tipe kepemimpinan yang pokok yang sering kita lihat dalam kehidupan sosial, terutama kehidupan di sekolah yaitu : Tipe Otokratis, Tipe Laissez faire, Tipe Demokratis, Tipe Pseudo Demokratis. Semntara itu menurut Nawawi (1995) gaya kepemimpinan terdiri dari tiga pola dasar yaitu : 1) Gaya kepemimpin yang berpola mementingkan pelaksanaan tugas, 2) Gaya kepemimpinan yang berpola mementingkan pelaksanaan hubungan kerja sama, 3) Gaya kepemimpinan yang berpola mementingkan hasil yang dapat dicapai dalam rangka mewujudkan tujuan kelompok atau organisasi. 
Peran kepala sekolah dalam memajukan pendidikan disadari sangat berat, karena seorang kepala sekolah berdasarkan pendapat yang dikemukan ahli dan diperkuat oleh peraturan pemerintah harus tidak hanya sebagai seorang pemimpin akan tetapi kepala sekolah harus mampu melakukan peran - peran lainnya seperti educator, manager, administrator, supervisor, leader, innovator, dan motivator. Peranan ini tidak ditemukan dalam lembaga organisasi profit. Menurut Mulyasa (2011) seorang kepala sekolah mempunyai peran yang sangat komplek yaitu educator, manager, administrator, supervisor, leader, innovator, dan motivator (EMASLIM).

Setiap kepala sekolah berkenginan untuk menjadikan sekolahnya menjadi sekolah efektif. Namun untuk menjadi sekolah efektif harus didahului oleh kepemimpinan yang efektif, untuk menjadi pemimpin yang efektif kepala sekolah harus memiliki pemahaman mendalam tentang tugas kepemimpinannya. Mulyadi (2010) menyatakan Kepemimpinan kepala sekolah yang efektif sangat menentukan keberhasilan sekolah. Sekolah yang efektif atau sukses hampir selalu ditentukan kepemimpinan kepala sekolah sebagai kunci kesuksesan. Kepala sekolah tidak hanya memberi layanan saja tetapi juga menjaga segala sesuatu lancar dan terus menerus memilahara kerukunan, mencurahkan waktu, energy, intelek dan emosi untuk memperbaiki sekolah. Dengan demikian untuk dapat menjadi kepala yang berhasil maka harus memiliki sejumlah kompetensi atau kemampuan. Dalam Permendiknas Nomor 13 Tahun 2007 menjelaskan ada lima (5) standar kompetensi yang harus dimiliki oleh kepala sekolah atau Madrasah yaitu : 1) kompetensi kepribadian, 2) kompetensi manajerial, 3) kompetensi kewirausahaan,4) kompetensi supervisi dan 5) kompetensi sosial.

\section{Akreditasi Sekolah}

Menurut keputusan Menteri

Pendidikan Nasional Republik Indonesia tahun 2003 pasal 1 ayat 3 Akreditasi Sekolah adalah suatu kegiatan penilaian kelayakan suatu sekolah berdasarkan kriteria yang telah ditetapkan dan dilakukan oleh Badan Akreditasi Sekolah yang hasilnya diwujudkan dalam bentuk pengakuan peringkat kelayakan.

Kualitas penyelenggaraan pendidikan pada berbagai lembaga pendidikan cukup bervariasi.Hal ini bisa diamati dari berbagai aspek, baik aspek yang terkait dengan masukan instrumental,seperti kurikulum tenaga pengajar, bahan ajar, atau masukan lingkungan, seperti kondisi lingkungan fisik dan kemampuan manajerial kepala sekolah, aspek yang terkait dengan proses, seperti proses belajar-mengajar dan sarana serta prasarana yang dibutuhkan, maupun aspek yang terkait dengan keluaran, seperti hasil ujian dan keterserapan lulusan sebagai tenaga kerja.Salah satu upaya meningkatkan mutu lulusan dan kualitas pendidikan dasar yang dilakukan Menteri Pendidikan Nasional adalah mengeluarkan keputusan No. 087/U/2002 tentang Akreditasi Sekolah. Keputusan tersebut kemudian diperkuat dengan UU No. 20 tahun 2003 tentang Sistem Pendidikan Nasional, yang kemudian dijabarkan dalam PP No. 19 tahun 2005 tentang Standar Nasional 
Pendidikan (SNP) yang lahir kemudian. Keputusan Mendiknas di atas dengan tegas menunjuk seluruh sekolah agar diakreditasi, baik sekolah negeri maupun swasta. Hal ini merupakan kemajuan yang luar biasa karena sebelumnya Ditjen Dikdasmen melalui keputusan Dirjen No. 020/C/Kep/1/1983 menyebutkan akreditasi hanya diberlakukan untuk sekolah swasta.

Dengan adanya proses akreditasi tersebut, akuntabilitas lembaga penyelenggara pendidikan pada jenjang pendidikan dasar dapat diketahui dari peringkat akreditasi yang dimiliki sekolah. Hal ini sesuai dengan ayat 2 Pasal $60 \mathrm{UU}$ No. 20 tahun 2003 yang menyatakan bahwa akreditasi terhadap program dan satuan pendidikan dilakukan pemerintah dan/lembaga mandiri yang berwenang sebagai bentuk akuntabilitas publik. Peringkat akreditasi tersebut harus benarbenar menggambarkan kualitas sekolah sehingga masyarakat memperoleh gambaran yang jelas tentang kualitas sekolah.

Untuk memperoleh gambaran atas terselenggaranya layanan pendidikan berdasarkan standar nasional pendidikan (SNP) maka Kemdikbud menyusun intrumen sebagai alat ukur dalam akreditasi yang tercakup dalam delapan Standar Nasional Pendidikan (SNP) yang terdiri dari 1) Standar Kompetensi Lulusan, 2) Standar Isi, 3) Standar Proses, 4) Standar Pendidik dan Tenaga Kependidikan, 5) Standar Sarana dan Prasarana, 6) Standar Pengelolaan Pendidikan, 7) Standar Pembiayaan Pendidikan, 8) Standar Penilaian Pendidikan.

Sekolah yang akan diakreditasi terlebih dahulu harus mempersiapkan berbagai bukti fisik yang diminta dalam istrumen akreditasi yang mencakup kepada delapan standar. Bukti fisik yang dimaksud berupa dokumen kegiatan-kegiatan pembelajaran seperti perangkat pembelajaran, dokumen 1 dan 2 KTSP, kegiatan sekolah, perencanaan dan pelaksanaan laporan keuangan sekolah, sarana dan prasarana pendidikan. Proses akreditasi dimulai dengan pengisian EDS oleh sekolah kemudian disampaikan kepada BAS Kabupaten untuk selanjutnya dinilai kelayakannya. Setelah itu Asesor melakukan visitasi untuk melakukan pengecekan lansung kondisi nyata delapan standar SNP di sekolah tersebut.

Untuk memperoleh hasil akreditasi yang terbaik maka kepala sekolah harus mempersiapkan segala dokumen yang dibutuhkan. Sehingga diperlukan kerja sama seluruh komponen sekolah seperti kepala sekolah, guru, walimurid dan komite sekolah. Kepemimpinan kepala sekolah sangat menentukan keberhasilan sekolah dalam mencapai hasil akreditasi yang maksmal. Kepala sekolah harus mempu menggerakkan, memotivasi, membagi tugas ataupun mempengaruhi seluruh warga sekolah agar bersedia bekerja sama mecapai tujuan yang telah ditetapkan.

\section{METODE PENELITIAN}

Jenis penelitian yang digunakan dalam penelitian ini adalah penelitian deskritif melalui pendekatan kualitatif dalam rancangan studi kasus. Menurut Bogdan \& Taylor (2006) metodologi kualitatif sebagai prosedur penelitian yang menghasilkan data deskriptif berupa kata-kata tertulis atau lisan dari orang-orang dan perilaku yang diamati. 
Adapun alasan peneliti menggunakankan jenis penelitian ini adalah karena masalah yang diteliti kompleks, holistik, dinamis dan sarat makna.Pemilihan studi kasus dalam penelitian ini dianggap cocok karena akan menjawab pertanyaan yang berhubungan dengan bagaimana gaya kepemimpinan kepala sekolah dalam mencapai akreditasi A di SDN Luak Bayau Sulit Air.

Studi kasus Yin menurut( 2006) merupakan metode penelitian yang cocok digunakan bilamana pokok pertanyaan suatu penelitian berkaitan dengan "bagaimana" dan "mengapa", di mana fokus penelitiannya terletak pada fenomena kontemporer (masa kini) di dalam konteks kehidupan nyata, dan peneliti hanya memiliki sedikit peluang atau tak mempunyai peluang sama sekali untuk mengontrol peristiwa yang akan diselidiki.Untuk memperoleh data yang terkait dengan penelitian ini peneliti menggunakan metode wawancara dan dokumentasi.

Jenis wawancara yang digunakan adalah semi terstruktur dengan menggunakan teknik wawancara mendalam (in-depth interview). Dalam hal ini peneliti melakukan wawancara dengan kepala sekolah SDN 24 Luak Bayau Sulit Air, ketua komite sekolah dan Guru - guru SDN 24 Luak Bayau.

Sedangkan untuk memmperkuat hasil penelitian digunakan metode dokumentasi yang berfungsi sebagai penguat terhadap suatu informasi yang diperoleh dari wawancara.Dokumen pendukung dalam penelitian ini seperti SK Tim akreditasi sekolah, notulen rapat, foto - foto kegiatan dan lainnya yang berhubungan dengan kegiatan akreditasi SDN 24 Luak Bayau Sulit Air.

Analisis data dalam penelitian ini dilakukan melalui tahapan yaitu data reduction, data display, dan conclusion/ drawing/verificatioan. Adapun pengujian keabsaahan data yang telah diperoleh dari wawancara dan dokumentasi menggunakan uji kredibilitas dengan cara triangulasi sumber Informasi yang diperoleh dari kepala sekolah akan diekplorasi melalui wawacara dengan ketua komite sekolah dan majelis guru SDN 24 Luak Bayau Sulit Air ( guru kelas dan mata pelajaran ).Data dari sumber-sumber tersebut dideskripsikan, dikategorisasikan mana yang memiliki pandangan sama, pandangan berbeda dan mana yang spesifik.

\section{HASIL PENELITIAN DAN PEMBAHASAN}

Berdasarkan deskripsi data penelitian yang diperoleh dari wawancara dan dokumentasi maka didapatkan gambaran bagaimana gaya kepemimpinan kepala sekolah SDN 24 Luak Bayau Sulit Air dalam mempengaruhi bawahannya untuk mencapai tujuan organisasi dalam hal ini mencapai akreditasi A. Cara /gaya, perilaku ataupun tindakan mempengaruhi bawahannya tersebut dapat terlihat dalam cara kepala sekolah berkomunikasi dengan warga sekolah, membagi tugas, melakukan pengawasan dan menggerakkan bawahan atau warga sekolah dalam mencapai akreditasi A. 
Gaya Kepemimpinan kepala sekolah dalam berkomunikasi untuk mencapai akreditasi A.

Gaya atau cara Kepala SDN 24 Luak Bayau Sulit Air dalam memimpin warga sekolah dalam mencapai akreditasi A dengan menggunakan pola komunikasi dua arah dan demokratis. kepala sekolah sangat terbuka menerima masukan dari para guru, hubungan kepala sekolah dengan warga sekolah terjalin tidak hanya sebatas hubungan kerja, tetapi antarguru dan kepala sekolah terjalin silaturrahmi yang baik, selain itu kepala sekolah terbuka tentang segala hal yang berkaitan dengan sekolah terutama masalah keuangan. Gaya komunikasi kepala sekolah terlihat dalam gaya bicaranya yang ceplas-ceplos atau nyiyir dengan selalu mengingatkan tugas tugas yang harus diselesaikan guru. Disamping itu juga kepala sekolah juga intensif memnjalin komunikasi dengan stakeholder untuk berpartisipasi dalam pemenuhan standar nasional pendidikan yaitu dengan perantau Sulit Air.

Komunikasi yang efektif akan menjadi sumber kekuatan untuk mewujudkan tujuan organisasi karena seluruh aspek manajemen dapat dilaksanakan secara terorganisir. Setiap anggota organisasi selalu membutuhkan komunikasi dalam bekerjasama dengan sesama anggota maupun dengan lingkungan yang merupakan sumber kedinamisan organisasi. Menurut Helmawati (2014 : 63) Sebagai pemimpin seorang kepala sekolah atau madrasah harus memiliki banyak kemampuan (multitalented). Kemampuan berkomunikasi bagi kepala sekolah atau madrasah merupakan salah satu kunci keberhasilannya dalam kepemimpinannya.

Sutisna (1983:190-191) memberikan pernyataan tentang pentingnya komunikasi dalam organisasi, yaitu :

a. Unsur-unsur esensial suatu organisasi melingkupi suatu maksud bersama, orang-orang yang bersedia membantu tercapainya tujuan bersama, saling berkomunikasi. Tanpa komunikasi tiada maksud atau tujuan bersama akan dipahami dan diterima oleh semua anggota organisasi. Juga tidak akan ada usaha yang dikoordinasikan untuk mencapai suatu tujuan.

b. Apabila komunikasi tidak berjalan semestinya, maksud-maksud atau tujuan mungkin tidak akan dipahami sama sekali dan orang akan cenderung untuk berbuat dengan cara sewenang-wenang dan tidak terkoordinasi.

c. Komunikasi dalam organisasi bermaksud memberi pengertian kepada orang-orang di dalam organisasi tentang maksudmaksud atau tujuan organisasi. Setiap anggota organisasi emahami tujuan organisasinya banyak ditentukan oleh lancar/ tidaknya pola-pola komunikasi para anggotanya. Melalui proses komunikasi ini lah, para pimpinan dan anggota organisasi dapat melaksanakan proses-proses organisasi.

\section{Gaya kepemimpinan kepala sekolah membagi tugas warga sekolah dalam mencapai akreditasi A.}

Pembagian tugas yang jelas akan lebih memudahkan dalam pelaksanaan tugas dalam sebuah organisasi. Hasil dari proses pengorganisasian atau menyangkut 
penetuan pekerjaan, pembagian kerja, penetapan mekanisme untuk mengkoordinasikan kegiatan adalah struktur organisasi. Struktur organisasi merupakan perwujudan yang menunjukkan korelasi atau hubungan dalam menjalankan sebuah fungsi dan peran dari masingmasing bagian dalam sebuah organisasi. Tugas dan peran tersebut nantinya dapat mempermudah sebuah kerjasama yang jelas dan terarah dalam menentukan suatu tujuan yang diharapkan oleh sekolah.

Dalam membagi tugas penyusunan tugas warga sekolah dalam mengumpulkan bahan akreditasi sekolah kepala SDN 24 Luak Bayau menggunakan gaya kepemimpinan partisipatif hal ini terlihat dari kepala sekolah membagi tugas kepada majelis guru sesuai dengan kemampuannya berdasarkan delapan standar nasional pendidikan seperti standar pembiayaan dikerjaan oleh bendahara BOS, disamping itu adanya kepercayaan kepala kepada bawahan untuk menyelesaikan pekerjaan. Hal ini ini menunjukkan ciri kepemimpinan partisipatif.

Gaya kepemimpinan partisipasif adalah gaya yang sesuai untuk tingkat kematangan mampu akan tetapi tidak memiliki kemauan untuk melakukan tanggungjawab atau tugas, karena ketidakmauan atau ketidakyakinan mereka untuk melakukan tugas dan tangungjawab seringkali disebabkan karena kurang keyakinan. Dalam kasus seperti ini pemimpin perlu membuka komunikasi dua arah dan secara aktif mendengarkan usahausaha yang dilakukan para bawahan atau pengikut.
Gaya kepemimpinan partisipatif menurut Thoha (2001:162) memberikan ciri-ciri partisipatif sebagai berikut :

1. Pimpinan memberikan dukungan tinggi dan pengarahan rendah. Posisi control atas pemecahan masalah dan pengambilan keputusan dipegang secara bergantian antara pimpinan dan bawahan.

2. Komunikasi dua arah ditingkatkan. Pimpinan mendengarkan bawahan secara aktif.

Kepemimpinan partisipatif juga dikenal dengan istilah kepemimpinan terbuka, bebas atau non directive. Tjiptono dalam Rivai (2003:162) menyebutkan bahwa Pemimpin yang menganut pendekatan terbuka hanya sedikit memegang kendali dan proses pengambilan keputusan. Ia hanya sedikit menyajikan informasi mengenai suatu permasalahan dan memberikan kesempatan kepada anggota tim untuk mengembangkan strategi dan pemecahannya, ia hanya mengerahkan tim kearah tercapainya consensus.

\section{Gaya kepemimpinan kepala sekolah dalam melakukan pengawasan terhadap warga sekolah dalam mencapai akreditasi A.}

Pengawasan merupakan proses pengamatan dari seluruh kegiatan organisasi guna menjamin bahwa semua pekerjaan yang sedang dilakukan sesuai dengan rencana yang telah ditentukan sebelumnya. Sebagai fungsi organisasi, pengawasan merupakan salah satu tugas mutlak diselenggarakan oleh semua orang yang menduduki jabatan manajerial, mulai dari manajer puncak hingga manajer rendah 
yang secara langsung mengendalikan kegiatan-kegiatan teknis yang diselenggarakan oleh semua petugas operasioanal.

Pengawasan berfungsi sebagai pengendali dan jaminan terhadap pencapaian tujuan yang telah ditetapkan. Kepala sekolah SDN 24 Luak Bayau Sulit Air melakukan pengawasan terhadap pekerjaan pengumpulan bahan akreditasi sekolah dengan sering bertanya, mengingatkan. Dalam pengawasan ini kepala sekolah menggunakan gaya kepemimpinan yang berorientasi tugas dan mementingkan hubungan dengan bawahan.

$$
\text { Gaya kepemimpinan yang }
$$

berorientasi pada tugas terlihat dalam hal kepala sekolah memberi target pekerjaan yang harus diberikan berdasarkan waktu yang ditentukan apabila pekerjaan itu belum selesai kepala sekolah melakukan penekanan kepada warga sekolah. Sementara itu juga kepala sekolah juga menggunakan gaya kepemimpinan yang berorientasi pada hubungan dimana kepala sekolah senantiasa menjaga hubungan baik antar sesama warga sekolah, adanya hubungan kekeluargaan kepala sekolah dengan warga sekolah, adanya hubungan yang harmonis dan kebersamaan dalam sekolah.

Berdasarkan pendekatan perilaku dalam kepemimpinan maka terdapat dua jenis gaya kepemimpinan yaitu gaya berorientasi tugas dan gaya berorientasi hubungan. Nanang Fatah (1996:93) Mengemungkakan berbagai gaya perilaku pemimpin berfokus pada dua gaya dasar yang berorientasi pada tugas " concern for production". dikemukakan juga bahwa mengemukakan dua gaya pokok kepemimpinan yang disebut "relationship motivated leader dan task, motivated leaders".

Kecenderungan dari dua gaya yang mementingkan tugas/hasil sebagai berikut memberi informasi dan pandangan, merencanakan informasi dan menyusun pendapat, Selalu memberi langkah awal, memberi pengarahan, merengkumkan,mengadakan perbaikan dan sebagainya sebaliknya, suka membantu, kompromi atau harmoni,berusaha menghilangkan ketegangan. membantu terjalinnya komunikasi.

\section{Gaya Kepemimpinan kepala sekolah dalam menggerakkan warga sekolah dalam mencapai akreditasi A.}

Penggerakan merupakan

keseluruhan usaha, cara, teknik, dan metode untuk mendorong para anggota organisasi agar mau dan ikhlas bekerja dengan sebaik mungkin demi tercapainaya tujuan organsisasi dengan efisien, efektif, dan ekonomis. Adapun cara kepala sekolah SDN 24 Luak Bayau Sulit Air dalam menggerakkan warga sekolah dalam mencapai akreditasi A

\section{a. Keteladanan}

Dalam memimpin warga sekolah kepala sekolah senantiasa memberikan contoh kepada warga sekolah dalam berbagai aspek seperti disiplin kehadiran. Beliau ikut langsung bekerja bersama sama guru ketika beliau meminta guruguru lembur sampai sore dalam mempersiapkan bahan akreditasi, maka beliau juga ikut lembur, contoh lainnya beliau terjun langsung membimbing guru dalam menyiapkan bahan akreditasi. Sebagai kepala sekolah memiliki 
integritas yang kuat yang ditunjukkan oleh satunya perkataan dan perbuatan.Keteladanan inilah yang berpengaruh kepada warga sekolah mau bekerja optimal dalam mencapai akreditasi sekolah.

Robin (1986:263) berpendapat bahwa keberhasilan dan kegagalan organisasi banyak ditentukan oleh keberhasilan dan kegagalan pemimpin dalam menggerakkan pemimpin dalam memainkan perannya . peran pemimpin dalam menggerakkan anggota memiliki peran strategik.

Pemimpin harus berperan sebagai individu teladan, sebagai komandan, sebagai ibu/bapak yang bijak, sebagai sahabat yang penuh pengertian. Dalam sejarah kepemimpinan Nabi Muhammad SAW kunci keberhasilan beliau sebagai pemimpin ummat dengan menjalankan konsep uswatun hasanah yaitu memberi keteladanan kepada para pengikutnya dan cara itu sangat efektif dalam menggerakkan dan mmendorong para sahabat untuk berjuang menyebarkan nilai - nilai ajaran Islam yang rabmatal lil lamiin.

Rasulullah sebagai pemimpin pasukan Islam juga ikut berjuang bersama kaum muslimin, ketika perang Khandak beliau juga ikut serta menggali parit bersama para sahabat sebagai mana hadis yang diriwayatkan oleh Bukhari dari Al-Barra yang berbunyi :

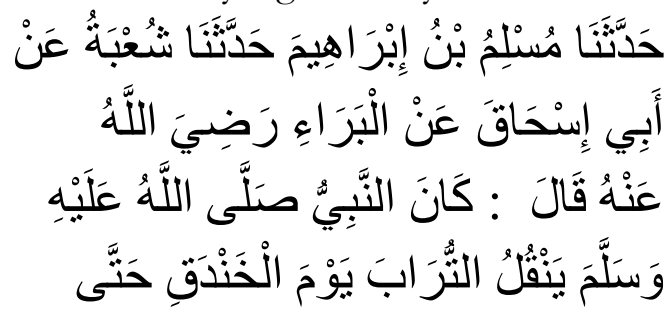

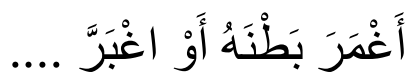

Telah menceritakan kepada kami Muslim bin Ibrabim telab menceritakan kepada kami Syu'bah dari Abu Ishaq dari Al Barra' radliallabu 'anbu dia berkata, "Nabi ${ }^{3}{ }^{2}$ perang Khandaq, hingga perutnya penuh debu -atau perutnya berdebu. (Shahih Bukhari no. 3795 kitab tentang perang Khandak )

Gaya kepemimpinan kepala sekolah sangat berpengaruh terhadap semangat kerja guru. Menurut Wahjosumidjo (1999:108) Kepala madrasah pada hakekatnya adalah sumber semangat bagi para guru, staf dan siswa. Oleh karena itu kepala sekolah harus selalu membangkitkan semangat, percaya diri terhadap para guru, staf dan siswa sehingga mereka memahami tujuan sekolah secara antusias, bekerja secara bertanggungjawab dan profesional.

\section{b. Motivasi}

Bentuk motivasi yang diberikan oleh kepala sekolah dengan mengajak guruguru pergi refresing atau jalan - jalan, akan tetapi motivasi ini tidak menjadi hal terlalu penting bagi para guru, namun faktor yang utama yang menyebabkan tingginya semangat kerja para guru adalah keiikutsertaan kepala sekolah dalam setiap kegiatan akreditasi di sekolah.sudah menjadi bagian semangat kerja bagi guru seperti yang diungkapkan oleh salah seorang guru SDN 24 Luak Bayau Sulit Air :

Dengan ikut sertanya ibu kepala sekolah dalam bekerja sudah menjadi 
motivasi bagi kami,ibu memerintahkan misalnya ibu wati bagian ini harus selesai,ini harus selesai,kemudian ibu itu pergi,ibu itu tidak seperti itu ..ibu itu kalau kita perlu lembur,ibu itu juga ikut lembur mungkin reward yang lain tidak terlalu penting,yang penting ibu itu ikut dengan keteladanan itu guru sudah termotivasi untuk bekerja. (Sukmawati, Wawancara tanggal 21 Desember 2016).

Setiap organisasi menggunakan berbagai reward atau imbalan untuk menarik dan mempertahankan orang dan memotivasi mereka agar mencapai tuiuan pribadi mereka dan tujuan organisasi. Misalnya saja dengan cara memberikan kepada pegawai berupa sertifikat penghargaan, alih tugas, promosi, pujian dan pengakuan dan juga membantu menciptakan iklim yang menghasilkan pekerjaan yang lebih banyak tantangannya dan memuaskan.

\section{c. Integritas Keperibadian.}

Kepala SDN Luak Bayau Sulit Air dalam memimpin warga sekolah dalam mencapai tujuan sekolah diantaranya mencapai akreditasi A memiliki corak yang tersendiri, watak dan karakter keperibadian, hal ini yang menjadi penggerak warga sekolah mau bekerja secara sukarela mencapai tujuan organisasi.

Gaya kepemimpinan kepala SDN 24 Luak Bayau Sulit Air dalam pandangan guru-guru adalah keras, disiplin, jujur, tegas dan memberi teladan. Meskipun keras dan tegas kepala SDN 24 Luak Bayau Sulit Air tetap mau menerima masukan dari bawahannya, kedisiplinannya terlihat pada harus lengkapnya perangkat pembelajaran seluruh guru.

Dalam pelaksanaan tugas yang diberikan oleh kepala sekolah terlihat beliau tipe kepala sekolah yang berorientasi pada tugas. Tugas - tugas yang diberikan kepada guru harus selesai sesuai dengan target yang diberikan apabila tidak selesai beliau tidak bosan bosan menagih tugas tersebut sampai selesai bahkan sedikit menekan agar cepat selesai. Ciri khas lain dari kepemimpinan kepala SDN 24 Luak Bayau Sulit Air adalah beliau orangnya ceplas-ceplos atau cerewet terutama dalam pelaksanaan tugas yang diberikan kepada guru-guru.

Dari paparan di atas dapat terungkap bahwa kemauan dan kerelaan dari warga sekolah SDN 24 Luak Bayau Sulit Air untuk bekerja dalam mencapai tujuan sekolah dipengaruhi oleh faktor dalam diri kepala sekolah itu sendiri memilki sifat tegas, jujur, disiplin,menepati janji, teladan,mau menerima masukan, ada rasa humor dan ditopang oleh kompetensi beliau yang dianggap mampu oleh warga sekolah.

Hal ini sesuai dengan salah satu pendekatan dalam melihat keberhasilan seorang pemimpin dalam memimpin bawahannya yaitu teori sifat. Berdasarkan pendekatan sifat, bahwa keberhasilan seorang pemimpin ditentukan oleh sifat-sifat, perangai atau ciri-ciri yang dimiliki oleh pemimpin itu, sifat-sifat tersebut dapat berupa sifat fisik dan dapat pula sifat psikologis. Atas dasar pemikiran tersebut timbul anggapan bahwa untuk menjadi seorang 
pemimpin yang berhasil sangat ditentukan oleh kemampuan pribadi seorang pemimpin. Berdasarkan studi trait apporoach ada tiga macam sifat pribadi seseorang pemimpin yang meliputi :

1. Ciri-ciri fisik (physical characteristics) seperti tinggi badan, penampilan, energi.

2. Kepribadian (personality) seperti menjunjung tinggi harga diri, berpengaruh, stabilitas emosi.

3. Kemampuan atau kecakapan (ability) seperti kecerdasan umum, lancar berbicara keaslian dan wawasan sosial. (Wahjosumidjo, 1999 : 21-22).

Mulyasa

(2009:

menambahkan keperibadian kepala sekolah sebagai Leader akan tercermin dalam sifat-sifat (1) jujur, (2) percaya diri, (3) tanggung jawab, (4) berani mengambil resiko dan keputusan, (5) berjiwa besar, (6) emosi yang stabil, (7) teladan.

Berdasarkan deskripsi data dan pembahasan hasil penelitian maka didapatkan gaya kepemimpinan kepala sekolah SDN 24 Luak Bayau Sulit Air dalam mempengaruhi bawahannya untuk mencapai tujuan organisasi dalam hal ini mencapai akreditasi A terlihat dalam cara, perilaku ataupun tindakan mempengaruhi bawahannya diantaranya dalam cara kepala sekolah berkomunikasi dengan warga sekolah, membagi tugas, melakukan pengawasan dan menggerakkan bawahan atau warga sekolah dalam mencapai akreditasi A. Berdasarkan hal tersebut maka dapat disimpulkan gaya kepemimpinan kepala SDN 24 Luak Bayau Sulit Air dalam mencapai akreditasi A antara lain gaya kepemimpinan demokratis dan partisipasif, gaya kepemimpinan yang berorientasi tugas dan hubungan, dengan kekhasan gaya kepemimpinan komunikatif dan terbuka serta apa adanya.

\section{PENUTUP}

Gaya kepemimpinan kepala sekolah SDN 24 Luak Bayau Sulit Air dalam proses mencapai akreditasi A adalah 1) gaya kepemimpinan demokratis hal ini terlihat aktifitas kepala sekolah yang selalu menjalin komunikasi dengan berbagai pihak terbuka menerima masukan, adanya pembagian tanggung jawab melalui tim akreditasi sekolah, membangun kerja sama tim, kepala sekolah menjadi sosok yang dapat diteladani dan menjadi katalisator yang menjembatani antarwarga sekolah.2) gaya kepemimpinan yang berorientasi kepada tugas (task oriented) dan berorientasi kepada hubungan (buman relation). Hal ini ditunjukkan dengan pemberian target pekerjaan yang harus diselesaikan dan sebaliknya juga kepala sekolah selalu menjaga hubungan baik antarwarga sekolah dengan kepala sekolah.

Keteladanan yang ditujukkan oleh kepala sekolah berpengaruh kepada semangat dan motovasi kerja warga sekolah. Motivasi yang diberikan oleh kepala sekolah mampu meningkatkan semangat kerja warga sekolah, baik berupa reward materil dan moril .

Komunikasi merupakan faktor penting yang dilakukan oleh kepala sekolah 
dalam mencapai akreditasi A. Dengan komunikasi dua arah, kepala sekolah terbuka menerima masukan dari warga sekolah, serta intens berkomunikasi dengan pihak luar sekolah stakeholder dan komite sekolah gaya komunikasi yang bersifat terbuka dan dilakukan dalam situasi formal maupun informal dalam suasana yang kekeluargaan, homoris.

\section{KEPUSTAKAAN ACUAN}

Al-Anas , al-Saburi Abi al-Husein al-Muslim bin al-Hajjaj, Sobih aL-Muslim, Jus II, Beirut: Darul al-Fikr, 1993.

BADAN AKREDITASI NASIONAL SEKOLAH/MADRASAH, Pedoman Akreditasi Sekolah/Madrasah, Jakarta: BAN S/M, 2014.

Dr. T.O. Adeyemi, Dr. R. Bolarinwa, Principals' Leadership Styles and Student Academic Performance in Secondary Schools in Ekiti State, HR Mars Nigeria International Journal of Academic Research in Progressive Education and Development January 2013, Vol. 2, No. 1 ISSN: 2226-6348

Fattah, Nanang, Landasan Manajemen Pendidikan. Bandung: Rosdakarya. 1996

Helmawati, Meningkatkan Kinerja Kepala Sekolab/Madrasah Melalui Manajerial Skiils. Jakarta : Reneka Cipta, 2014.

Mulyadi, Kepemimpinan Kepala Sekolah dalam Mengembangkan Mutu. Malang: UIN Maliki Press, 2010.
Mulyasa, E. Manajemen Berbasis Sekolah, Bandung: PT Remaja Rosdakarya, 2004.

Nawawi, Hadari dan Martini, Kepemimpinan yang Efektif. Yogyakarta: Gadjah Mada University Press, 1995.

Sagala,Syaiful, Kemampuan Profesional Guru dan Tenaga Kependidikan, Pemberdayaan Guru, Tenaga Kependidikan dan Masyarakat dalam Manajemen Sekolah, Bandung: Alfaeta, 2009.

Sugiyono. Metode Penelitian Pendidikan: Pendekatan Kuantitatif, Kualitatif, Dan R\&D. Bandung: Alfabeta, 2012.

Sutisna, Oteng. Administrasi Pendidikan Dasar Teoritis Untuk Praktek Profesional. Bandung: Angkasa.,1983.

Thoha, Miftah Kepemimpinan dalam Manajemen, Jakarta: PT Raja Grapindo., 2006.

Tim Dosen Jurusan Administrasi Pendidikan FIP IKIP Malang, Administrasi Pendidikan,Malang: IKIP Malang, 1989.

Yin, Robert K.Studi kasus: Desain dan Metode. (rev. ed.), Jakarta: PT Raja Grafindo Persada. 2006.

Wahjosumidjo. Kepemimpinan Kepala Sekolah Tinjauan Teoritik dan Permasalahannya, Jakarta: PT RajaGrafindo Persada, 2013. 